\title{
Fatty acid composition of the meat from Mos breed and commercial strain capons slaughtered at different ages
}

\author{
By O. Díaz, L. Rodríguez, A. Torres and A. Cobos* \\ Área de Tecnología de Alimentos. Departamento de Química Analítica, Nutrición y Bromatología. \\ Facultad de Ciencias. Universidad de Santiago de Compostela. 27002 Lugo. Spain \\ *Corresponding author: angel.cobos@usc.es
}

\section{RESUMEN}

Composición de ácidos grasos de la carne de capones de raza Mos y estirpes comerciales sacrificados a diferentes edades.

Se ha estudiado la influencia de la raza [Mos (raza española autóctona), Sasso T-44 y X-44 (estirpes comerciales)] y la edad (5, 6, 7 y 8 meses) de los capones (gallos castrados) en la composición de ácidos grasos de la carne de la pechuga y del muslo. La carne de los capones de raza Mos presentó menor concentración de ácidos grasos monoinsaturados y mayor de poliinsaturados que la carne de las otras razas. Además, dichos capones mostraron mayor contenido de los ácidos margárico $(\mathrm{C} 17: 0)$ y esteárico (C18:0) que las estirpes comerciales; sin embargo, no hubo diferencias significativas entre las distintas razas en el total de ácidos grasos saturados. La carne de los animales más jóvenes mostró menor concentración de ácidos grasos monoinsaturados y mayor de poliinsaturados que la de los animales de mayor edad. Sin embargo, la edad influyó menos que la raza.

PALABRAS CLAVE: Ácidos grasos - Edad - Gallos castrados - Raza.

\section{SUMMARY}

Fatty acid composition of the meat from the Mos breed and commercial strain capons slaughtered at different ages.

The influence of the breed [Mos (Spanish indigenous breed), Sasso T-44 and X-44 (commercial strains)] and the age (5, 6, 7 and 8 months) of capons (castrated male cockerels) on the fatty acid compositions of breast and drumstick meat were studied. The meat of the Mos capons showed lower contents of monounsaturated fatty acids and higher concentrations of polyunsaturated fatty acids than those of the other breeds. In addition, the Mos breed showed higher contents of margaric acid (C17:0) and stearic acid (C18:0) as compared to the commercial strains; however, no significant effects of breed were observed in the total contents of saturated fatty acids in the meat. The meat of the youngest animals showed lower contents of monounsaturated fatty acids and higher concentrations of polyunsaturated fatty acids than that of the older ones. Nevertheless, the effect of age was less important than the effect of breed.

KEY-WORDS: Age - Breed - Castrated male cockerel Fatty acids.

\section{INTRODUCTION}

The capon (castrated male cock) of Vilalba is a traditional product that is usually consumed on Christmas day. Capons of the Mos breed (Galician indigenous breed) grown until they are 8 months old have been traditionally used. However, capons of lower age (from 5 months old) and different breeds (commercial strains) are now commercialized.

In an earlier paper (Díaz et al., 2010), we highlighted the effects of the breed [Mos, Sasso T-44 and X-44 (commercial strains)] and the age (5, 6,7 and 8 months) of capons on their chemical compositions and their physico-chemical properties $(\mathrm{pH}$, water holding capacity, color and texture) of the breast and drumstick meat. Our results showed that chemical composition, $\mathrm{pH}$, water holding capacity, drip loss, color and texture of the meat were significantly influenced by the breed and age of the capons.

The fatty acid composition of the meat is an important factor due to its health and texture implications; the breed and the age of the capons might also modify the fatty acid composition of the meat. There are few studies about the fatty acid composition of capons (Tor et al., 2005; Miguel et al., 2008; Sirri et al., 2009). However, there is no information regarding the effects of breed and age on fatty acid composition of these animals.

The objective of this study was to determine the influence of the breed [Mos, Sasso T-44 and X-44 (commercial strains)] and the age (5, 6, 7 and 8 months) of capons on the fatty acid composition of the breast and drumstick meat.

\section{MATERIALS AND METHODS}

\subsection{Animals and diet}

One hundred and fifty 1-day-old male chicks were used in the experiment, 50 were the Mos slow-growing breed (Avimos, Ourense, Spain), 50 were the Sasso T-44 slow growing strain and the 
other 50 were the Sasso X-44 medium growing strain (Sasso, Sabres, France). They were housed separately in three indoor pens $\left(24 \mathrm{~m}^{2}\right.$ each one) with access to grass paddocks (333 $\mathrm{m}^{2}$ each one) in free range conditions. They grew contemporarily in order to avoid the influence of different environment conditions. Castration was performed at 48 days of age for the T-44 and X-44 strains and at 60 days of age for the Mos chickens. These ages are the most adequate for castration according to the Asociación de Criadores de Capón de Vilalba (Association of Capon Growers in Vilalba). All birds were castrated bilaterally using the surgical method described by LópezBeceiro et al. (1992) and in accordance with EU regulations. The absence of testicular regeneration was determined by visual assessment in live animals and also after slaughtering.

The castrated cockerels were fed ad libitum the same commercial diet. This diet was mainly composed of corn, soybean meal and wheat dried distiller grains with solubles and contained $200 \mathrm{~g} \mathrm{~kg}^{-1}$ crude protein, $40 \mathrm{~g} \mathrm{~kg}^{-1}$ cellulose fiber, $42 \mathrm{~g} \mathrm{~kg}^{-1}$ crude fat and $60 \mathrm{~g} \mathrm{~kg}^{-1}$ ash. The fatty acid composition of their diet is shown in Table 1. When the animals reached the predetermined age for sampling (at 5, 6,7 and 8 months, i.e. at 150, 180, 210 and 240 days, respectively), five animals from each breed were randomly selected and they were stunned, killed by manual exsanguination, plucked, completely eviscerated (obtaining the ready-to-cook carcass) and weighed. Then, they were refrigerated at $4{ }^{\circ} \mathrm{C}$ for 24 hours until analyses. A total of 60 animals (20 of each breed) were analyzed. The carcass weights of the capons are shown in Table 2 (adapted from Diaz et al., 2010).

Table 1

Fatty acid composition of the diet

\begin{tabular}{lr}
\hline Fatty acid & \multicolumn{1}{c}{$\%$} \\
\hline C14:0 & 0.71 \\
C15:0 & 0.70 \\
C16:0 & 17.82 \\
C17:0 & 0.25 \\
C18:0 & 7.35 \\
SFA & 26.83 \\
C17:1 & 0.17 \\
C18:1n-9 & 32.93 \\
C20:1 & 0.70 \\
MUFA & 34.71 \\
C18:2n-6 & 36.06 \\
C18:3n-3 & 2.39 \\
PUFA & 38.45 \\
\hline
\end{tabular}

SFA, MUFA, PUFA: saturated, monounsaturated and polyunsaturated fatty acids, respectively.

\subsection{Sampling and analytical methods}

The left side of the carcasses were quartered according to the standard procedures of Jensen (1983). The meat from left breast and drumstick was obtained by carefully separating the flesh from the bones. The skin, subcutaneous fat and bones were not included in the samples. The meat samples were finely minced in a blender (Polytron PT 10-35). Lipids were extracted and purified from the former homogenate with a chloroform:methanol mixture $(1: 1 \mathrm{v} / \mathrm{v})$ according to the method of Hanson and Olley (1963). The total lipids were gravimetrically determined. All analyses were made in duplicate. The lipid contents of the breast and drumstick meat of the capons are shown in Table 2 (adapted from Diaz et al., 2010).

The fatty acid composition of meat lipids was determined by gas liquid chromatography of methyl esters prepared in basic conditions (potassium hydroxide in methanol). The gas chromatograph was a Hewlett-Packard apparatus (HP 5890) equipped with a dual flame ionization detector. The capillary column (30 m, internal diameter $0.25 \mathrm{~mm}$ ) was packed with OV-225 $(0.1 \mu \mathrm{m})$ on fused silica. Hydrogen was used as the carrier gas under constant pressure $(110 \mathrm{kPa})$. Analysis was performed using an initial isothermal period $\left(150^{\circ} \mathrm{C}\right.$, $2 \mathrm{~min})$; thereafter the temperature was increased to $210^{\circ} \mathrm{C}$ at an increasing rate of $4^{\circ} \mathrm{C} \mathrm{min}^{-1}$, and finally an isothermal period $\left(210^{\circ} \mathrm{C}, 15 \mathrm{~min}\right)$ was established. The injector and detector were maintained at $250^{\circ} \mathrm{C}$. A Hewlett-Packard HP3394A integrator was used for quantitative analyses. The identification of different fatty acid methyl esters was performed by comparison of the retention times with those of authentic standards (Sigma). The amounts of fatty acids were expressed as a percentage of total area of injected methyl esters. All analyses were made in duplicate.

\subsection{Statistical analyses}

Data were evaluated statistically using the SPSS version 12.0 for Windows (2004) program. A two-way ANOVA was used to analyze the effects of the breed and age and their interaction on the parameters determined. These analyses were carried out using the GLM procedure. When breed $\times$ age interactions were not detected, the means of each breed or age group were compared using the Tukey F-test with significance at $p<0.05$. When breed $x$ age interactions were detected, a one-way ANOVA was used and the means of each breed within each age or the means of each age within each breed were compared using the Tukey F-test with significance at $p<0.05$.

\section{RESULTS}

The saturated fatty acid composition of the breast meat of the different types of capons is 
Table 2

Carcass weight $(\mathrm{g})$ of capons and lipid content $(\mathrm{g} / \mathrm{kg})$ of breast meat and drumstick meat

\begin{tabular}{|c|c|c|c|c|c|c|}
\hline & \multirow[t]{2}{*}{ Breed } & \multicolumn{4}{|c|}{ Age (months) } & \multirow[b]{2}{*}{ PSD } \\
\hline & & 5 & 6 & 7 & 8 & \\
\hline \multirow[t]{3}{*}{ Carcass weight } & Mos & $2,645.4$ & $2,883.0$ & $3,208.6$ & $3,666.3$ & 360.23 \\
\hline & $\mathrm{T}-44$ & $3,410.0$ & $4,143.4$ & $4,066.4$ & $4,359.8$ & \\
\hline & $X-44$ & $4,041.8$ & $4,270.0$ & $4,688.4$ & $4,814.3$ & \\
\hline \multirow{3}{*}{$\begin{array}{l}\text { Breast meat } \\
\text { lipids }\end{array}$} & Mos & 36.06 & 53.92 & 51.64 & 65.70 & 10.39 \\
\hline & T-44 & 50.43 & 45.14 & 49.40 & 43.16 & \\
\hline & $X-44$ & 40.15 & 49.38 & 47.80 & 43.80 & \\
\hline \multirow{3}{*}{$\begin{array}{l}\text { Drumstick meat } \\
\text { lipids }\end{array}$} & Mos & 50.60 & 67.16 & 68.46 & 67.23 & 12.34 \\
\hline & $\mathrm{T}-44$ & 70.33 & 67.86 & 89.26 & 93.52 & \\
\hline & $X-44$ & 73.12 & 84.26 & 92.63 & 89.92 & \\
\hline
\end{tabular}

PSD $=$ Pooled standard deviation.

shown in Table 3. The total content of saturated fatty acids was around $34 \%$. The main saturated fatty acid was palmitic (25\%) followed by stearic acid (8\%). No significant effects of breed and age were observed in the total contents of saturated fatty acids of the breast meat; however, the Mos breed showed a significantly lower content of C16:0 and a higher content of $\mathrm{C} 17: 0$ and $\mathrm{C} 18: 0$ as compared to Sasso strains. Breed $\times$ age interactions were observed for C14:0 and C15:0.

The monounsaturated fatty acid composition of the breast meat of the different types of capons is shown in Table 3 . The total content of monounsaturated fatty acids was around $42 \%$. The main monounsaturated fatty acid was oleic acid (33\%). Significant effects of breed were observed in the total contents of monounsaturated fatty acids of the breast meat. The Mos breed showed a significantly lower content of monounsaturated fatty acids than the commercial strains. The values of $\mathrm{C} 14: 1, \mathrm{C} 16: 1 \mathrm{n}-7$ (in 5, 6 and 7 month birds), C18:1n-9 and C18:1n-7 (in 8 month animals) for the Mos breed were significantly lower than in the T-44 and X-44 strains. However, the Mos breed showed a significantly higher content of $\mathrm{C} 17: 1$ than the other breeds. Significant effects of age were observed in the total contents of monounsaturated fatty acids of the breast meat. The youngest animals (5 months) showed lower contents of monounsaturated fatty acids than the older ones.

The polyunsaturated fatty acid composition of the breast meat of the different types of capons is shown in Table 3. Linoleic acid was the most abundant $(18 \%)$ followed by arachidonic (3-6\%) and linolenic (0.7-0.9\%) acids. The total content of polyunsaturated fatty acids was around $24 \%$. Significant effects of breed and age were observed in the total contents of polyunsaturated fatty acids of the breast meat. The Mos breed showed significantly higher contents of C18:2 n-6, C18:3 n-3 and total polyunsaturated fatty acids than the T-44 and X-44 strains. The youngest animals (5 months) showed higher contents of C18:3 n-3 and polyunsaturated fatty acids than the older ones. Breed $x$ age interactions were observed for arachidonic acid. The Mos breed showed a significantly higher content of C20:4 n-6 than the other strains only in the 5 month birds and the content of this fatty acid was significantly higher in 5 month animals than in older ones only in the Mos breed.

The saturated fatty acid composition of the drumstick meat of the different types of capons is shown in Table 4. The total content of saturated fatty acids was around $34 \%$. The main saturated fatty acid was palmitic (24.4\%) followed by stearic acid (8.6\%). The Mos breed showed significantly higher contents of C15:0, C17:0 and C18:0 than the other strains; however, no significant effects of breed were observed in the main saturated fatty acid (C16:0) and in the total content of saturated fatty acids of the drumstick meat. When the age of the animals was taken into account, the oldest animals (8 months) showed lower C15:0 and C16:0 values and total contents of saturated fatty acids than the younger ones.

The monounsaturated fatty acid composition of drumstick meat of the different types of capons is shown in Table 4 . The total content of monounsaturated fatty acids was around $41.5 \%$. The main monounsaturated fatty acid was oleic acid (32.8\%). The Mos breed showed significantly lower contents of monounsaturated fatty acids than the other breeds. The values of C14:1, C16:1 n-7 and $\mathrm{C} 18: 1 \mathrm{n}-9$ for the Mos breed were lower than in the T-44 and X-44 strains. Significant effects of age were observed in the total contents of monounsaturated fatty acids of the breast meat. The youngest animals (5 months) showed lower 
Table 3

Effect of breed and age of capons in the fatty acid composition of breast meat

\begin{tabular}{|c|c|c|c|c|c|c|c|c|c|c|c|c|}
\hline \multirow{2}{*}{$\begin{array}{l}\text { Fatty } \\
\text { acid }\end{array}$} & \multicolumn{4}{|c|}{ Breed } & \multicolumn{5}{|c|}{ Age (months) } & \multicolumn{3}{|c|}{ Analysis of variance } \\
\hline & & Mos & $\mathrm{T}-44$ & $X-44$ & 5 & 6 & 7 & 8 & PSD & Breed & Age & Interaction \\
\hline \multirow[t]{3}{*}{ C14:0 } & Mos & & & & $\mathrm{x} 0.68 \mathrm{a}$ & $0.73 a b$ & $0.83 b$ & $0.81 b$ & 0.08 & * & NS & ** \\
\hline & $\mathrm{T}-44$ & & & & $x y 0.75 a$ & $0.87 b$ & $0.80 a b$ & $0.81 a b$ & & & & \\
\hline & $X-44$ & & & & y0.85 & 0.87 & 0.74 & 0.82 & & & & \\
\hline \multirow[t]{3}{*}{ C15:0 } & Mos & & & & 0.12 & $x 0.13$ & $x 0.13$ & $x 0.12$ & 0.00 & $\star \star \star \star ~$ & ** & ** \\
\hline & $\mathrm{T}-44$ & & & & $0.12 \mathrm{a}$ & y0.09ab & $x y 0.12 a$ & y0.08b & & & & \\
\hline & $X-44$ & & & & $0.13 a$ & $x y 0.12 a b$ & y0.10bc & $\mathrm{y} 0.08 \mathrm{c}$ & & & & \\
\hline $\mathrm{C} 16: 0$ & & $23.88 \mathrm{a}$ & $25.51 b$ & $25.62 b$ & 25.01 & 25.11 & 24.58 & 25.61 & 1.40 & ** & NS & NS \\
\hline C17:0 & & $0.23 a$ & $0.16 b$ & $0.17 b$ & $0.20 \mathrm{a}$ & $0.20 \mathrm{a}$ & $0.20 \mathrm{a}$ & $0.15 b$ & 0.03 & 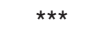 & ** & NS \\
\hline C18:0 & & $8.77 a$ & $7.97 \mathrm{~b}$ & $7.78 b$ & 8.17 & 8.17 & 8.33 & 7.85 & 0.58 & $* * *$ & NS & NS \\
\hline SFA & & 33.73 & 34.54 & 34.50 & 34.26 & 34.42 & 34.01 & 34.52 & 1.50 & NS & NS & NS \\
\hline C14:1 & & $0.08 a$ & $0.12 b$ & $0.12 b$ & $0.10 a b$ & $0.13 a$ & $0.09 b$ & $0.11 a b$ & 0.03 & $\star \star * *$ & * & NS \\
\hline C16:1n-9 & & 0.78 & 0.84 & 0.83 & 0.76 & 0.74 & 0.83 & 0.96 & 0.35 & NS & NS & NS \\
\hline \multirow[t]{3}{*}{ C16:1n-7 } & Mos & & & & $\mathrm{x} 1.77 \mathrm{a}$ & x2.39ab & $\mathrm{x} 1.77 \mathrm{a}$ & $3.18 b$ & 0.69 & $* * *$ & NS & * \\
\hline & $\mathrm{T}-44$ & & & & $x y 2.97$ & $y 4.06$ & y2.96 & 3.63 & & & & \\
\hline & $X-44$ & & & & y3.56 & $\mathrm{z} 3.22$ & y3.25 & 2.63 & & & & \\
\hline C17:1 & & $0.15 a$ & $0.11 b$ & $0.13 a b$ & 0.13 & 0.13 & 0.14 & 0.11 & 0.03 & ** & NS & NS \\
\hline C18:1n-9 & & $33.32 a$ & $34.07 a b$ & $34.66 \mathrm{~b}$ & 33.33 & 34.43 & 34.36 & 34.20 & 1.41 & $* * *$ & NS & NS \\
\hline \multirow[t]{3}{*}{ C18:1n-7 } & Mos & & & & 3.54 & 3.21 & 3.67 & $x 2.60$ & 0.74 & * & NS & * \\
\hline & $\mathrm{T}-44$ & & & & 3.46 & 3.11 & 3.40 & $y 4.05$ & & & & \\
\hline & $X-44$ & & & & 2.90 & 4.01 & 4.27 & y4.42 & & & & \\
\hline C20:1 & & $0.38 a$ & $0.34 a b$ & $0.32 b$ & $0.34 a b$ & $0.37 a b$ & $0.37 a$ & $0.30 \mathrm{~b}$ & 0.06 & * & NS & NS \\
\hline MUFA & & $40.21 a$ & $42.36 b$ & $43.10 \mathrm{~b}$ & 40.77 & 42.45 & 42.23 & 42.69 & 2.00 & $\star \star \star *$ & * & NS \\
\hline C18:2n-6 & & $19.31 a$ & $16.86 b$ & $16.82 b$ & 17.82 & 17.38 & 17.81 & 17.22 & 1.78 & $\star \star \star *$ & NS & NS \\
\hline C18:3n-3 & & 0.95 & 0.74 & 0.74 & $0.87 a$ & $0.82 a b$ & $0.75 b$ & $0.76 b$ & 0.12 & $\star \star * *$ & * & NS \\
\hline \multirow[t]{3}{*}{ C20:4n-6 } & Mos & & & & $x 6.26 a$ & $3.52 b$ & $3.71 b$ & $2.94 b$ & 1.09 & NS & ** & * \\
\hline & $\mathrm{T}-44$ & & & & xy4.43 & 3.46 & 4.13 & 3.40 & & & & \\
\hline & $X-44$ & & & & y3.33 & 3.82 & 3.33 & 3.36 & & & & \\
\hline C22:4n-6 & & 0.64 & 0.67 & 0.56 & 0.70 & 0.56 & 0.59 & 0.63 & 0.18 & NS & NS & NS \\
\hline C22:5n-3 & & 0.40 & 0.39 & 0.36 & 0.42 & 0.33 & 0.39 & 0.39 & 0.13 & NS & NS & NS \\
\hline C22:6n-3 & & 0.49 & 0.56 & 0.47 & 0.58 & 0.44 & 0.49 & 0.52 & 0.16 & NS & NS & NS \\
\hline PUFA & & $26.03 a$ & $23.10 \mathrm{~b}$ & $22.40 \mathrm{~b}$ & 24.97 & 23.13 & 23.76 & 22.79 & 2.28 & 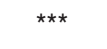 & * & NS \\
\hline
\end{tabular}

PSD $=$ Pooled standard deviation. NS $=$ not significant $(p>0.05) ;{ }^{*} p<0.05 ;{ }^{* *} p<0.01 ;{ }^{* \star *} p<0.001 ; a, b, c$ : Means within a row and effect (breed or age) followed by different letters differ significantly $(p<0.05) ; x, y, z$ : Means within a column and fatty acid preceded by different letters differ significantly $(p<0.05)$; SFA = Saturated fatty acids; MUFA = Monounsaturated fatty acids; PUFA $=$ Polyunsaturated fatty acids.

contents of monounsaturated fatty acids than the oldest ones (8 months).

The polyunsaturated fatty acid composition of drumstick meat of the different types of capons is shown in Table 4. The total content of polyunsaturated fatty acids was around $24 \%$. The main fatty acid was C18:2 n-6 (19.6\%) followed by C20:4 n-6 (2.5\%) and
C18:3 n-3 (0.9\%). Significant effects of breed were observed in all the polyunsaturated fatty acids of the breast meat. The Mos breed showed significantly higher contents of polyunsaturated fatty acids than the other strains. The youngest animals (5 months) showed higher contents of polyunsaturated fatty acids than the older ones. 
Table 4

Effect of breed and age of capons in the fatty acid composition of drumstick meat

\begin{tabular}{|c|c|c|c|c|c|c|c|c|c|c|c|c|}
\hline \multirow{2}{*}{$\begin{array}{l}\text { Fatty } \\
\text { acid }\end{array}$} & \multicolumn{4}{|c|}{ Breed } & \multicolumn{5}{|c|}{ Age (months) } & \multicolumn{3}{|c|}{ Analysis of variance } \\
\hline & & Mos & $\mathrm{T}-44$ & $X-44$ & 5 & 6 & 7 & 8 & PSD & Breed & Age & Interaction \\
\hline $\mathrm{C} 14: 0$ & & 1.02 & 0.98 & 0.93 & 0.97 & 1.02 & 1.00 & 0.91 & 0.13 & NS & NS & NS \\
\hline C15:0 & & $0.15 a$ & $0.12 b$ & $0.11 b$ & $0.12 a b$ & $0.14 a$ & $0.14 a$ & $0.10 \mathrm{~b}$ & 0.03 & $* * *$ & $* \star *$ & NS \\
\hline $\mathrm{C} 16: 0$ & & 24.08 & 24.36 & 24.78 & $24.20 a b$ & $25.35 a$ & $24.40 a b$ & $23.66 \mathrm{~b}$ & 1.59 & NS & * & NS \\
\hline $\mathrm{C} 17: 0$ & & $0.25 a$ & $0.19 b$ & $0.18 b$ & 0.20 & 0.20 & 0.22 & 0.19 & 0.04 & $\star \star \star \star ~$ & NS & NS \\
\hline C18:0 & & $9.44 a$ & $8.26 b$ & $8.07 b$ & 8.58 & 8.29 & 8.97 & 8.30 & 0.76 & $\star \star \star \star ~$ & NS & NS \\
\hline SFA & & 34.94 & 33.90 & 34.07 & $34.07 a b$ & $35.01 \mathrm{a}$ & $34.73 a b$ & $33.15 b$ & 1.66 & NS & * & NS \\
\hline C14:1 & & $0.12 a$ & $0.18 b$ & $0.16 \mathrm{ab}$ & $0.15 a b$ & $0.19 a$ & $0.13 b$ & $0.14 b$ & 0.04 & $\star *$ & $\star *$ & NS \\
\hline C16:1n-9 & & 0.58 & 0.79 & 0.78 & 0.58 & 0.77 & 0.78 & 0.80 & 0.31 & NS & NS & NS \\
\hline C16:1n-7 & & $3.11 a$ & $4.71 b$ & $4.61 b$ & 4.29 & 4.51 & 3.63 & 4.19 & 0.96 & $* * *$ & NS & NS \\
\hline C17:1 & & 0.16 & 0.14 & 0.15 & 0.16 & 0.15 & 0.15 & 0.13 & 0.03 & NS & NS & NS \\
\hline C18:1n-9 & Mos & & & & $x 30.75 a$ & $31.69 a b$ & x29.98a & $32.92 b$ & 1.51 & $\star \star \star *$ & NS & * \\
\hline & $\mathrm{T}-44$ & & & & x33.91 & 32.88 & y32.61 & 34.46 & & & & \\
\hline & $X-44$ & & & & xy32.34 & 33.12 & y35.26 & 33.91 & & & & \\
\hline C18:1n-7 & & 3.14 & 3.51 & 3.44 & $2.72 a$ & 3.23ab & $3.70 \mathrm{~b}$ & $4.01 b$ & 0.90 & NS & ** & NS \\
\hline C20:1 & & 0.32 & 0.29 & 0.28 & 0.32 & 0.30 & 0.29 & 0.28 & 0.06 & * & NS & NS \\
\hline MUFA & & $38.59 a$ & $43.03 b$ & $43.01 b$ & $40.65 a$ & $41.72 a b$ & $41.33 a$ & $43.46 \mathrm{~b}$ & 1.86 & $* * *$ & $\star *$ & NS \\
\hline C18:2n-6 & & $21.07 a$ & $19.03 b$ & $18.93 b$ & 20.36 & 19.08 & 19.57 & 19.27 & 1.72 & $\star \star$ & NS & NS \\
\hline C18:3n-3 & & $1.06 \mathrm{a}$ & $0.86 \mathrm{~b}$ & $0.84 b$ & $1.03 a$ & $0.94 a b$ & $0.85 \mathrm{bc}$ & $0.80 \mathrm{c}$ & 0.12 & $\star * *$ & $\star \star *$ & NS \\
\hline C20:4n-6 & & $2.98 a$ & $2.23 b$ & $2.22 b$ & 2.66 & 2.33 & 2.44 & 2.33 & 0.64 & ** & NS & NS \\
\hline C22:4n-6 & & $0.59 a$ & $0.47 \mathrm{~b}$ & $0.45 b$ & $0.59 a$ & $0.42 b$ & $0.51 a b$ & $0.46 a b$ & 0.14 & $\star *$ & ** & NS \\
\hline C22:5n-3 & & $0.28 a$ & $0.21 b$ & $0.21 b$ & 0.25 & 0.21 & 0.24 & 0.23 & 0.08 & ** & NS & NS \\
\hline C22:6n-3 & & $0.49 a$ & $0.28 b$ & $0.27 b$ & 0.40 & 0.30 & 0.34 & 0.31 & 0.10 & $\star \star \star *$ & NS & NS \\
\hline PUFA & & $26.48 a$ & $23.07 \mathrm{~b}$ & $22.92 b$ & $25.29 a$ & $23.27 \mathrm{~b}$ & 23.94ab & $23.39 a b$ & 2.06 & 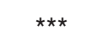 & * & NS \\
\hline
\end{tabular}

PSD = Pooled standard deviation. NS = not significant $(p>0.05) ;{ }^{*} p<0.05 ;{ }^{* *} p<0.01 ;{ }^{* *} p<0.001$; a,b,c: Means within a row and effect (breed or age) followed by different letters differ significantly $(p<0.05) ; x, y, z$ : Means within a column and fatty acid preceded by different letters differ significantly $(p<0.05)$; SFA = Saturated fatty acids; MUFA = Monounsaturated fatty acids;

PUFA = Polyunsaturated fatty acids.

\section{DISCUSSION}

The fatty acid composition of the Mos capon meat from 7-month-olds was similar to that reported by Tor et al. (2005) in the breasts and drumsticks of Penedesenca Negra capons slaughtered at 28 weeks of age; however, the total content of polyunsaturated fatty acids of Penedesenca Negra capons was higher probably due to the arachidonic acid, which was not determined by these authors. The fatty acid composition of capons showed some differences with those reported by other authors. Miguel et al. (2008) observed a higher content of linoleic acid in the meat of Castellana Negra capons slaughtered at 29 weeks than in Mos capons at 7 months. This result could be attributed to differences between breeds or to the high content of linoleic acid (57.43\%) in their diet. It is well known that the fatty acid composition of chicken meat is influenced by the fatty acid composition of the diet (Cobos et al., 1994). Sirri et al. (2009) observed a higher content of linoleic acid in the meat of Hubbard $x$ Golden Comet capons processed at 180 days than in Mos, T-44 and X-44 capons at 6 months. These results were also probably due to the different breeds or to the different feeding regimen of the birds.

As mentioned in the Introduction section, there are no studies about the effect of breed on the fatty acid composition of capons. The meat of the Mos capons showed lower contents of monounsaturated fatty acids and higher concentrations of polyunsaturated fatty acids than that of the other breeds. Castellini et al. (2006) studied the effect of genotype on the fatty acid composition of chicken meat reared under the organic system (access to a grassed paddock). The meat of Kabir chickens had a higher content of total polyunsaturated fatty acids 
(PUFA), mainly n-3 PUFA compared with Ross birds. This result was probably due to the greater ingestion of grass by Kabir chickens. These authors mentioned that Ross chickens were less active, with less walking, more lying around and they spent more time indoors than outdoors with respect to the Kabir birds. Although in extensive conditions, it is very difficult to quantify the intake of grass (Pugliese et al., 2009), the content of PUFA is increased in meat by grass-based diets (Castellini et al., 2002). Although the capons were fed the same diet, different feeding behavior is possible. It has been reported that the indigenous chickens tend to scratch while eating and have been observed picking up feed particles more selectively than broilers (Van Marle-Koster and Webb, 2000). This might explain the differences between an indigenous breed (Mos) and selected strains (Sasso T-44 and $\mathrm{X}$-44). It is likely that the Mos capons ingested more grass than the T-44 and X-44 capons. The higher ingestion of pasture could also explain the higher content of C17:0 of the Mos breed as compared to the Sasso strains. Ros et al. (2001) observed a higher content of margaric acid in free-range chickens in relation to commercial broiler chickens. In pork, Cava (1997) reported a higher proportion of C17:0 in pigs fed with acorns and pasture than in pigs fed a commercial, concentrated diet. However, it is also possible that the differences in fatty acid composition could be related to genetic origin as has been described in pigs (Pascual et al., 2006), ducks (Schiavone et al., 2004) and rabbits (Hernández et al., 2008). Pascual et al. (2006) reported differences in the rate of deposition of fatty acids among breeds. Schiavone et al. (2004) suggest that the desaturation/elongation reactions and the mechanism implicated in the incorporation by muscles of the long chain polyunsaturated fatty acids might be more efficient in unselected rural strains than in selected for meat production strains.

The differences in fatty acid composition among breeds have also been explained by variations in the lipid contents of their muscles (Moloney, 2005). The Mos breed showed a lower lipid content in the drumstick meat as compared to the Sasso strains (Díaz et al., 2010). A high level of PUFA in meat has also been related to muscles with very low fat content consisting predominantly of phospholipids with high proportions of PUFA. In poultry meat, the level of PUFA in phospholipids is normally higher than in glycerides (Alasnier et al., 2000). However, no significant differences were observed in the lipid contents of breast meat between the Mos breed and the Sasso strains (Díaz et al., 2010). So, the differences in the fatty acid composition between Mos and Sasso strains could mainly be explained by the genotype and the feeding behaviour more than by the lipid content of the meat.

The meat of the youngest animals showed lower contents of monounsaturated fatty acids and higher concentrations of polyunsaturated fatty acids than that of the older birds. The differences in fatty acid composition between younger and older capons might also be related to the differences in lipid content of the muscles. Diaz et al. (2010) observed that the lipid content in drumstick meat increased with age in all breeds although the lipid content in breast meat only increased with age in Mos capons. Nevertheless, the effect of age was not as significant as the effect of breed. Poureslami et al. (2010) also observed that PUFA $n-3$ and $n-6$ in broiler breast meat decreased with age. Girolami et al. (2003) also reported that an increase in age at slaughter produced a decrease in total polyunsaturated fatty acids in ostrich meat. This fact was attributed to the higher content of meat lipids in older animals.

\section{CONCLUSIONS}

The Mos capon meat showed lower contents of monounsaturated fatty acids and higher concentrations of polyunsaturated fatty acids than the meat from the other breeds. These differences could mainly be explained by the genotype and the feeding behavior more than by the lipid content of the meat.

The meat of the youngest animals showed lower contents of monounsaturated fatty acids and higher concentrations of polyunsaturated fatty acids than that of the older ones. These differences could mainly be explained by the lipid content of the meat. Nevertheless, the effect of age was less important than the effect of the breed.

\section{ACKNOWLEDGMENTS}

This study was financially supported by project PGIDIT04RAG012E [Consellería de Innovación, Industria e Comercio da Xunta de Galicia and Asociación de Criadores de Capón de Vilalba].

\section{REFERENCES}

Alasnier C, David-Brinad E, Gandemer G. 2000. Hydrolytic and oxidative changes in the lipids of chicken breast and thigh muscles during refrigerated storage. J. Food Sci. 65, 9-14.

Castellini C, Dal Bosco A, Mugnai C, Pedrazzoli M. 2006. Comparison of two chicken genotypes organically reared: oxidative stability and other qualitative traits of the meat. Ital. J. Anim. Sci. 5, 29-42.

Castellini C, Mugnai C, Dal Bosco A. 2002. Effect of organic production system on broiler carcass and meat quality. Meat Sci. 60, 219-225.

Cava R. 1997. Efecto del sistema de alimentación en la composición y características de la grasa intramuscular del cerdo ibérico. En Bases de la calidad del jamón Ibérico. Junta de Extremadura, págs. 35-54.

Cobos A, Hoz L, Cambero MI, Ordoñez JA. 1994. Revisión: Influencia de la dieta animal en los ácidos grasos de los lípidos de la carne. Rev. Esp. Cienc. Tecnol. Aliment. 34, 35-51.

Díaz O, Rodríguez L, Torres A, Cobos A. 2010. Chemical composition and physico-chemical properties of meat from capons as affected by breed and age. Span. J. Agric. Res. 8, 91-99. 
Girolami A, Marsico I, D’Andrea G, Braghieri A, Napolitano F, Cifuni GF. 2003. Fatty acid profile, cholesterol content and tenderness of ostrich meat as influenced by age at slaughter and muscle type. Meat Sci. 64, 309-315

Hanson SWF, Olley J. 1963. Application of the Bligh and Dyer method of lipid extraction to tissue homogenates. Biochem. J. 89, 101P-102P.

Hernandez P, Cesari V, Blasco A. 2008. Effect of genetic rabbit lines on lipid content, lipolytic activities and fatty acid composition of hind leg meat and perirenal fat. Meat Sci. 78, 485-491.

Jensen FJ. 1983. Method of dissection of broiler carcass and description of parts. Papwoth's Pendragon Press, Cambridge, UK.

López Beceiro AM, Pereira Espinel JL, Barreiro Lois A. 1992. La castración de las aves domésticas: castración en el pollo. Servicio de Publicaciones. Diputación Provincial, Lugo, Spain.

Miguel JA, Ciria J, Asenjo B, Calvo JL. 2008. Effect of caponisation on growth and on carcass and meat characteristics in Castellana Negra native Spanish chickens. Animal 2, 305-311.

Moloney AP. 2005. The fat content of meat and meat products. In Kerry J, Kerry J, Ledward D (Eds.), Meat processing, Woodhead Publishing Limited, Cambridge , págs. 137-153.

Pascual JV, Rafecas M, Canela MA, Boatella J, Bou R, Baucells MD, Codony R. 2006. Effects of increasing amounts of a linoleic-rich dietary fat on the fat composition of four pig breeds. Part I: Backfat fatty acid evolution. Food Chem. 96, 538-548.

Poureslami R, Raes K, Huyghebaert G, De Smet S. 2010. Effects of diet, age and gender on the polyunsaturated fatty acid composition of broiler anatomical compartments. Brit. Poultry Sci. 51, 81-91.

Pugliese C, Sirtori F, Ruiz J, Martin D, Parentia S, Franci O. 2009. Effect of pasture on chestnut or acorn on fatty acid composition and aromatic profile of fat of Cinta Senese dry-cured ham. Grasas Aceites 60, 271-276.

Ros C, Díaz O, Cobos A. 2001. Chemical and fatty acid composition of "extra" and free-range chicken. Alimentaria 322, 45-50.

Schiavone A, Romboli I, Chiarini R, Marzoni M. 2004. Influence of dietary lipid source and strain on fatty acid composition of Muscovy duck meat. J. Anim. Physiol. a. Anim. Nutr. 88, 88-93.

Sirri F, Bianchi M, Petracci M, Meluzzi A. 2009. Influence of partial and complete caponization on chicken meat quality. Poultry Sci. 88, 1466-1473.

Tor M, Estany J, Francesch A, Cubiló MD. 2005. Comparison of fatty acid profiles of edible meat, adipose tissues and muscles between cocks and capons. Anim. Res. 54, 413-424.

Van Marle-Koster E, Webb EC. 2000. Carcass characteristics of South African native Chicken lines. S. Afr. J. Anim. Sci.30, 53-56.

Recibido: $17 / 1 / 12$ Aceptado: 2/4/12 